\title{
KANDUNGAN LEMAK PAKAN OPTIMAL UNTUK PERTUMBUHAN BENIH KEPITING BAKAU (Scylla paramamosain)
}

\author{
Nyoman Adiasmara Giri, Ketut Suwirya, Ibnu Rusdi, dan Muhammad Marzuqi
}

\begin{abstract}
ABSTRAK
Budi daya kepiting bakau belum berkembang baik terutama karena terbatasnya benih dan belum tersedianya pakan buatan. Saat ini riset pengembangan teknologi pembenihan kepiting bakau mulai menunjukkan keberhasilan. Riset ini bertujuan untuk mengetahui kebutuhan lemak dalam pakan bagi pertumbuhan benih kepiting bakau (Scylla paramamosain) sebagai informasi dasar untuk mengembangkan pakan buatan. Sebanyak 90 ekor benih kepiting bakau dipelihara pada 15 buah bak volume 30 liter. Setiap bak diisi 6 ekor kepiting yang dipisahkan secara individu dalam kurungan supernet. Kepiting diberi pakan 2 kali sehari berupa pelet kering dengan penambahan lemak berbeda sesuai perlakuan, yaitu $0 \%, 3 \%, 6 \%, 9 \%$, dan $12 \%$ selama 7 minggu. Pakan percobaan mempunyai kandungan protein yang sama dan dibuat isokalori dengan penambahan dekstrin. Hasil percobaan menunjukkan bahwa kandungan lemak pakan berpengaruh nyata $(P<0,05)$ terhadap bobot akhir, pertambahan bobot, lebar karapas, efisiensi pakan, dan lemak tubuh, namun tidak berpengaruh nyata $(P>0,05)$ terhadap sintasan dan kandungan protein tubuh benih kepiting bakau. Peningkatan kandungan lemak pakan juga meningkatkan kandungan lemak tubuh benih kepiting. Pakan percobaan dengan penambahan lemak $9 \%$ dan $12 \%$ menghasilkan pertumbuhan tertinggi dengan bobot akhir mencapai 3,66 dan $3,59 \mathrm{~g}$, atau tumbuh $1.775,2 \%$ dan $1.821,4 \%$. Hasil ini menunjukkan bahwa untuk tumbuh optimal benih kepiting bakau membutuhkan pakan dengan kandungan lemak $9--12 \%$.
\end{abstract}

ABSTRACT: Dietary lipid requirement for growth of mud crab, Scylla paramamosain juvenile. By: Nyoman Adiasmara Giri, Ketut Suwirya, Ibnu Rusdi, and Muhammad Marzuqi

Mud crab culture has not been well developed yet due to limited seed supply and unavailable good artificial feed. Recently, hatchery technology for seed production of mud crab shows significant progress. The study aims to know lipid requirement for growth of mud crab Scylla paramamosain juvenile as basic information for developing artificial feed. The experiment was conducted using 15 polycarbonate tanks of $30 \mathrm{~L}$ volume, equipped with flow-through water system. Six crablets from hatchery with initial weight of $0.19 \pm 0.08 \mathrm{~g}$ and carapace length of $1.06 \pm$ $0.05 \mathrm{~cm}$ were stocked individually in each tank using supernet. Crab were fed will experimental diet with different levels of lipid addition; i.e. $0 \%, 3 \%, 6 \%, 9 \%$, and $12 \%$ twice a day for 7 weeks. Feeds were prepared as dry pellet which have the same protein and energy contents. Results of the experiment showed that dietary lipid contents significantly $(P<0.05)$ affected final weight, weight gain, carapace length, feed efficiency (FE), and lipid content of juvenile mud crab. However, survivals of crab on all treatments were not significantly different $(P>0.05)$. Lipid contents of the juvenile mud crab increased with increasing dietary lipid addition. The highest final weight (3.66 g and $3.59 \mathrm{~g}$ ) was found on crab fed with diet with $9 \%$ and $12 \%$ lipid addition. Result of the experiment indicates that mud crab S. paramamosain juvenile required $9 \%-12 \%$ dietary lipid to support good growth.

KEYWORDS: Scylla paramamosain, lipid requirement, growth

\section{PENDAHULUAN}

Berdasarkan riset genetik dengan metode allozyme elektroforesis dan skuensing gen mt-DNA diketahui terdapat 4 spesies kepiting bakau, yaitu Scylla serrata, S. paramamosain, S. olivacea, dan S. tranquebarica (Keenan, 1997). Kepiting bakau (S. paramamosain) merupakan salah satu komoditas perikanan Indonesia. Total produksi kepiting Indonesia pada tahun 1997 mencapai 13.174 ton. Dari total produksi ini, $61,6 \%$ berasal dari penangkapan dan sisanya $38,4 \%$ merupakan hasil budi daya (Direktorat Jenderal Perikanan, 1999). Kendala utama dalam pengembangan budi daya kepiting bakau adalah

Peneliti pada Balai Besar Riset Perikanan Budidaya Laut, Gondol 
ketersediaan benih yang terbatas, karena benih belum dapat diproduksi secara terkontrol di hatcheri dan belum tersedianya pakan komersial (Cholik, 1999). Selama ini budi daya kepiting masih menggunakan benih yang ditangkap dari alam dan diberi pakan berupa ikan rucah (Fortes, 1999; Dat, 1999). Kepiting bakau dapat makan berbagai macam ikan rucah, juga dalam bentuk moist pellet (Sulaeman \& Hanafi, 1992). Dari analisis kebiasaan makannya diketahui bahwa kepiting bakau merupakan hewan pemakan segala yang terdiri atas $35,7 \%$ detritus; $23,6 \%$ ikan; dan $18,37 \%$ krustase (Prasad \& Neelakantan, 1988a). Pada pengamatan di laboratorium diketahui bahwa kepiting bakau juga dapat makan pakan buatan berupa pelet kering dengan baik (Chin et al., 1992; Giri et al., 2002; Millamena \& Quinitio, 1999). Marasigan (1999) melaporkan bahwa kepiting bakau (Scylla serrata) dan $S$. tranquebarica yang diberi pakan daging kerang menghasilkan pertumbuhan lebih baik dibandingkan dengan yang diberi pakan pelet udang atau cumi. Sedangkan kepiting bakau S. serrata yang diberi pakan ikan rucah pertumbuhannya tidak berbeda nyata dengan yang diberi pakan daging kerang. Kajian ekonomi terhadap budi daya kepiting bakau di tambak menunjukkan bahwa pakan merupakan komponen biaya terbesar dari biaya produksi (Cann \& Shelley, 1999). Namun demikian sampai saat ini belum tersedia pakan buatan secara komersial untuk kepiting bakau.

Pada pengembangan pakan buatan untuk kepiting diperlukan tersedianya informasi kebutuhan nutrien pakan baik makro maupun mikro nutriennya. Benih kepiting bakau membutuhkan pakan dengan kandungan protein $47,6 \%$ untuk dapat tumbuh baik (Giri et al., 2002). Chin et al. (1992) melaporkan bahwa kepiting bakau yang diberi pakan dengan kandungan protein 35\% dan $40 \%$ menghasilkan pertumbuhan yang tidak berbeda nyata. Di samping protein, lemak merupakan sumber energi penting untuk mendukung pertumbuhan dan sebagai sumber asam lemak esensial. Selain itu lemak juga merupakan media absorpsi dari sterol dan vitamin yang larut dalam lemak. Setelah protein, lemak selalu mendapat perhatian utama dalam penyusunan formula pakan untuk hewan budi daya. Riset ini bertujuan untuk mengetahui kebutuhan lemak untuk pertumbuhan benih kepiting bakau.

\section{BAHAN DAN METODE}

Benih kepiting bakau (crablet) diproduksi di hatcheri dengan menggunakan bak oval volume $5 \mathrm{~m}^{3}$. Sebanyak 90 ekor benih kepiting dengan bobot awal rata-rata $0,19 \mathrm{~g} \pm 0,08 \mathrm{~g}$ dan lebar karapas rata-rata $1,06 \mathrm{~cm} \pm 0,05 \mathrm{~cm}$ dipelihara secara individu dalam wadah supernet yang ditempatkan dalam bak volume $30 \mathrm{~L}$, dilengkapi dengan sistem air mengalir dan aerasi. Pada setiap bak percobaan dipelihara 6 ekor benih kepiting. Percobaan dirancang menggunakan rancangan acak lengkap dengan 5 perlakuan beda kandungan lemak dalam pakan dan setiap perlakuan terdiri atas 3 ulangan.

Pakan percobaan dengan penambahan lemak berbeda yaitu $0 \%, 3 \%, 6 \%, 9 \%$, dan $12 \%$ dibuat dalam bentuk pelet dan dikeringkan dengan pengering dingin (freeze dryer). Sebagai sumber protein pakan digunakan tepung ikan, tepung kepala udang, tepung hati cumi, tepung kedelai, dan kasein. Kandungan lemak tepung ikan, tepung hati cumi, dan tepung kedelai diekstrak menggunakan chloroform dan methanol sebelum digunakan sebagai bahan pakan buatan. Lemak pakan bersumber dari campuran minyak ikan dan minyak kedelai dengan perbandingan 2:1. Kandungan energi pakan dibuat sama dengan penambahan karbohidrat dari dekstrin. Komposisi pakan disajikan pada Tabel 1. Data analisis kandungan lemak pakan menunjukkan bahwa pakan tanpa penambahan minyak (L.p-0) mempunyai kandungan lemak 1,82\% (Tabel 1), yang merupakan akumulasi dari sisa lemak dalam bahan pakan yang telah diekstrak.

Pakan diberikan 2 kali setiap hari dengan jumlah disesuaikan dengan respon makan kepiting. Jumlah pakan yang diberikan dicatat setiap hari. Setiap minggu dilakukan penimbangan kepiting secara individu untuk mengetahui pertumbuhannya. Percobaan berlangsung selama 7 minggu. Untuk mengetahui pengaruh pakan percobaan, data pertumbuhan, sintasan, efisiensi pakan, dan kandungan protein, serta lemak tubuh kepiting dianalisis dengan ANOVA serta uji Tukey (Steel \& Torrie, 1960).

\section{HASIL DAN BAHASAN}

Bobot akhir benih kepiting setelah diberi pakan percobaan selama 7 minggu menunjukkan bahwa kandungan lemak pakan berpengaruh nyata terhadap pertumbuhan benih kepiting bakau $(P<0,05)$. Pertambahan bobot benih kepiting bakau yang diberi pakan tanpa penambahan lemak adalah paling rendah dan berbeda nyata $(P<0,05)$ dengan perlakuan lainnya. Perbedaan ini jelas terlihat setelah minggu ke-4 pemberian pakan percobaan (Gambar 1). Pertumbuhan paling tinggi $1.775,2 \%$ dan $1.821,4 \%$ diperoleh pada benih kepiting yang diberi pakan dengan penambahan lemak berturut-turut $9 \%$ dan $12 \%$ (Tabel 2). Pakan percobaan mempunyai kandungan protein dan energi yang sama, sehingga perbedaan respon pertumbuhan pada percobaan ini diduga dikarenakan adanya perbedaan pemanfaatan sumber energi. Benih kepiting yang diberi pakan tanpa penambahan lemak atau dengan lemak rendah akan 
Tabel 1. Komposisi pakan percobaan (\% bahan kering)

Table 1. Composition of the experimental diets (\% dry matter)

\begin{tabular}{|c|c|c|c|c|c|}
\hline \multirow{2}{*}{$\begin{array}{c}\text { Bahan } \\
\text { Ingredient }\end{array}$} & \multicolumn{5}{|c|}{ Pakan percobaan (Experimental diet) } \\
\hline & Lp-0 & Lp-3 & Lp-6 & Lp-9 & Lp-12 \\
\hline Kasein (Casein) & 25.0 & 25.0 & 25.0 & 25.0 & 25.0 \\
\hline Tepung ikan (Fish meal) & 29.0 & 29.0 & 29.0 & 29.0 & 29.0 \\
\hline Tepung kepala udang (Shrimp head meal) & 2.0 & 2.0 & 2.0 & 2.0 & 2.0 \\
\hline Tepung hati cumi (Squid liver meal) & 3.0 & 3.0 & 3.0 & 3.0 & 3.0 \\
\hline Tepung kedelai (Soybean meal) & 2.0 & 2.0 & 2.0 & 2.0 & 2.0 \\
\hline Tepung terigu (Wheat flour) & 2.5 & 2.5 & 2.5 & 2.5 & 2.5 \\
\hline Minyak kedelai (Soybean oil) & 0.0 & 1.0 & 2.0 & 3.0 & 4.0 \\
\hline Minyak ikan (Fish oil) & 0.0 & 2.0 & 4.0 & 6.0 & 8.0 \\
\hline Lecitin (Lecithin) & 2.0 & 2.0 & 2.0 & 2.0 & 2.0 \\
\hline Campuran mineral (Mineral mix ${ }^{1}$ ) & 3.0 & 3.0 & 3.0 & 3.0 & 3.0 \\
\hline Campuran vitamin (Vitamin mix $^{2}$ ) & 2.5 & 2.5 & 2.5 & 2.5 & 2.5 \\
\hline C M C (Binder) & 2.0 & 2.0 & 2.0 & 2.0 & 2.0 \\
\hline Dekstrin (Dextrin) & 27.0 & 22.3 & 15.9 & 9.4 & 3.0 \\
\hline Selulosa (Cellulose) & 0.0 & 1.7 & 5.1 & 8.6 & 12.0 \\
\hline \multicolumn{6}{|c|}{ Komposisi nutrien (Nutrients composition; \% D.M.) } \\
\hline Protein (Protein) & 48.2 & 48.1 & 48.0 & 48.4 & 48.0 \\
\hline Lemak (Lipid) & 1.82 & 3.9 & 6.8 & 9.7 & 12.5 \\
\hline Abu (Ash) & 13.6 & 12.0 & 12.5 & 12.6 & 12.2 \\
\hline Serat (Fibre) & 3.2 & 4.1 & 5.5 & 8.3 & 9.2 \\
\hline
\end{tabular}

1 Mineral mix (g/100 g diet): $\mathrm{K}_{2} \mathrm{HPO}_{4} 0.70 ; \mathrm{Ca}_{3}\left(\mathrm{PO}_{4}\right)_{2} 0.95 ; \mathrm{MgSO}_{4} \cdot 7 \mathrm{H}_{2} \mathrm{O} 1.07 \mathrm{NaH}_{2} \mathrm{PO}_{4} \cdot 2 \mathrm{H}_{2} \mathrm{O} 0.28$

2 Vitamin Mix (mg/100 g diet): p-Aminobenzoic acid 15.80; biotin 0.63; inositol 632.00; Ca-pantothenate 94.80; niacin 63.20; pyridoxine- $\mathrm{HCl} 18.96$; riboflavin 12.64 ; thiamin- $\mathrm{HCl} 6.32$; menadion 6.34 ; b-carotene 15.17; atocoferol 31.60; calciferol 1.90; cyanocobalamin 0.13 ; folic acid 1.26; choline-HCI 948.00 .
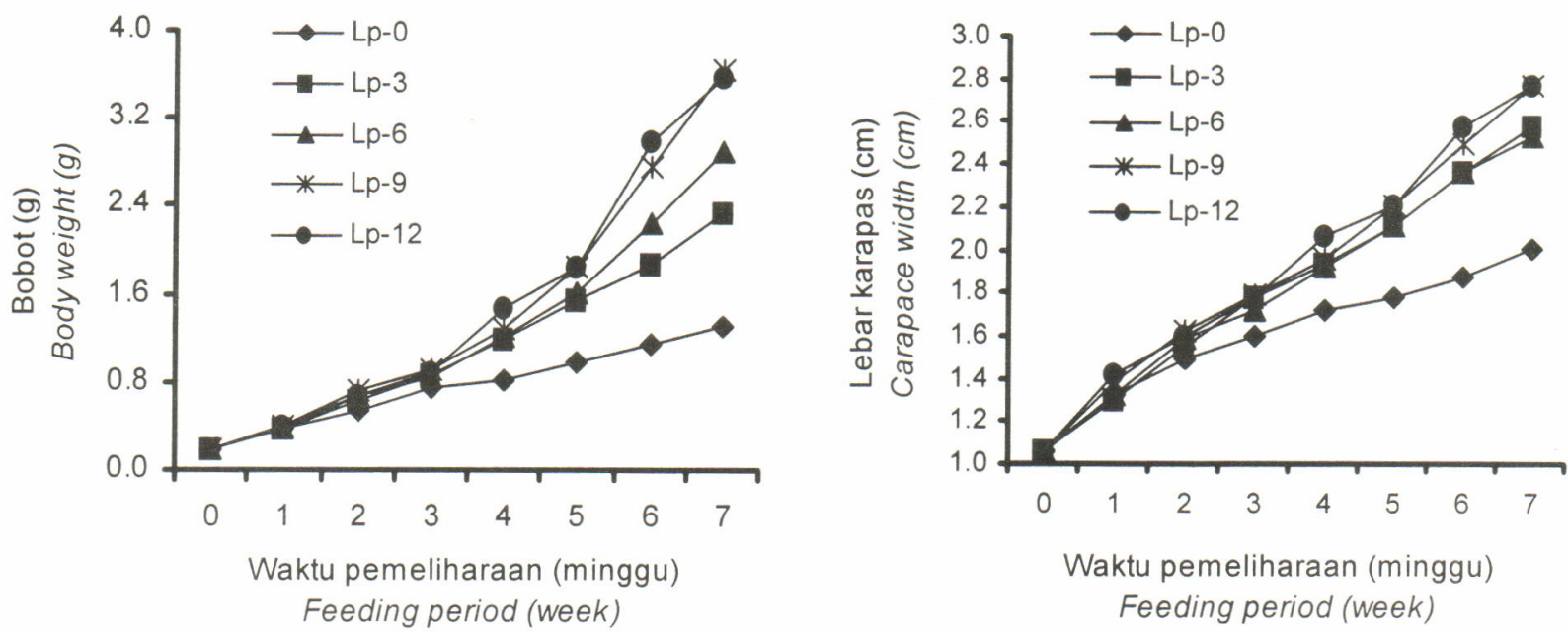

Gambar 1. Pertambahan bobot dan lebar karapas benih kepiting bakau, S. paramamosain selama percobaan Figure 1. Body weight and carapace width increment of mud crab juvenile during the feeding experiment

merombak lebih banyak protein untuk memenuhi kebutuhan energinya. Sebaliknya pada benih kepiting yang diberi pakan dengan kandungan lemak lebih tinggi memperoleh lebih banyak energi dari lemak sehingga protein dapat dimanfaatkan lebih efisien untuk pertumbuhan.

Keseimbangan rasio protein/energi pada krustase (khususnya udang) merupakan fenomena yang 
Tabel 2. Bobot akhir, pertambahan bobot, lebar karapas, dan sintasan benih kepiting bakau, S. paramamosain yang diberi pakan percobaan ${ }^{1}$

Table 2. Final weight, weight gain, carapace width, and survival of mud crab juvenile fed experimental diets

\begin{tabular}{ccccc}
\hline $\begin{array}{c}\text { Pakan percobaan } \\
\text { Experimental diet }\end{array}$ & $\begin{array}{c}\text { Bobot akhir } \\
\text { rata-rata } \\
\text { Final weight }\end{array}$ & $\begin{array}{c}\text { Pertambahan } \\
\text { bobot } \\
\text { Weight gain (\%) }\end{array}$ & $\begin{array}{c}\text { Lebar karapas } \\
\text { akhir } \\
\text { Carapace width }\end{array}$ & $\begin{array}{c}\text { Sintasan } \\
\text { Survival rate } \\
\text { (\%) }\end{array}$ \\
\hline Lp-0 & $1.30 \pm 0.19^{\mathrm{a}}$ & $622.2 \pm 80.1^{\mathrm{a}}$ & $2.01 \pm 0.10^{\mathrm{a}}$ & $88.9^{\mathrm{a}}$ \\
Lp-3 & $2.35 \pm 0.10^{\mathrm{b}}$ & $1,117.2 \pm 51.0^{\mathrm{b}}$ & $2.58 \pm 0.09^{\mathrm{b}}$ & $83.3^{\mathrm{a}}$ \\
Lp-6 & $2.90 \pm 0.21^{\mathrm{c}}$ & $1,498.2 \pm 116.3^{\mathrm{c}}$ & $2.53 \pm 0.08^{\mathrm{bc}}$ & $100^{\mathrm{a}}$ \\
Lp-9 & $3.66 \pm 0.38^{\mathrm{d}}$ & $1,775.2 \pm 107.0^{\mathrm{d}}$ & $2.77 \pm 0.11^{\mathrm{c}}$ & $88.9^{\mathrm{a}}$ \\
Lp-12 & $3.59 \pm 0.22^{\mathrm{d}}$ & $1,821.4 \pm 115.4^{\mathrm{d}}$ & $2.77 \pm 0.05^{\mathrm{c}}$ & $100^{\mathrm{a}}$ \\
\hline
\end{tabular}

Bobot awal (initial weight): $0.19 \mathrm{~g} \pm 0.08 \mathrm{~g}$; Lebar karapas awal (initial carapace width): $1.06 \mathrm{~cm} \pm 0.05 \mathrm{~cm}$ Nilai pada kolom dengan huruf yang sama tidak berbeda nyata $(P>0,05)$ (Values in the column with the same letter are not significantly different $(\mathrm{P}>0.05)$

menarik, di mana pakan dengan kandungan energi yang tinggi mengakibatkan konsumsi protein berkurang dan pertumbuhannya terhambat. Sebaliknya pakan dengan kandungan energi yang rendah mengakibatkan terjadinya perombakan protein untuk mencukupi kebutuhan energinya dan menghasilkan efisiensi protein yang rendah serta terhambatnya pertumbuhan udang (Cuzon \& Guillaume, 1997).

Lebar karapas yang merupakan salah satu parameter pertumbuhan kepiting, meningkat dengan bertambahnya kandungan lemak pakan. Lebar karapas tertinggi $(2,77 \mathrm{~cm})$ juga diperoleh pada kepiting yang diberi pakan dengan kandungan lemak $9 \%$ dan $12 \%$. Hasil percobaan ini menunjukkan bahwa benih kepiting bakau membutuhkan pakan dengan kandungan lemak $9 \%--12 \%$ untuk dapat tumbuh baik. Dibandingkan dengan kebutuhan lemak krustasea lainnya seperti udang yang berkisar antara $5 \%--8 \%$ (Sheen \& D'Abramo, 1991), kebutuhan lemak lobster Homarus americanus adalah $5 \%$ (Castell \& Covey, 1976), dan serak Procambarus acutus 6\% (Davis \&
Robinson, 1986). Dari data tersebut diketahui bahwa kebutuhan lemak kepiting bakau relatif lebih tinggi. Peningkatan kadar lemak pakan udang atau lobster yang melebihi kebutuhan optimal mengakibatkan pertumbuhan udang atau lobster terhambat, mungkin dikarenakan ketidakseimbangan nutrien sebagai sumber energi dan standar kualitas dari sumber lemaknya (Akiyama et al., 1991). Hal ini tidak terlihat pada kepiting bakau (S. paramamosain), di mana pada kadar lemak pakan $12 \%$ masih tumbuh normal walaupun tidak terjadi peningkatan pertumbuhan dibandingkan yang diberi pakan dengan kadar lemak $9 \%$.

Efisiensi pakan menunjukkan proporsi pakan yang dapat dimanfaatkan untuk pertumbuhan, meningkat dengan bertambahnya kandungan lemak pakan sampai pada leve/ $9 \%$. Peningkatan kandungan lemak pakan dari $9 \%$ menjadi $12 \%$ tidak meningkatkan efisiensi pakan secara nyata (Tabel 3). Hasil ini menunjukkan bahwa pakan dengan kandungan lemak $9 \%$ dan $12 \%$ memberikan efisiensi pakan tertinggi untuk benih kepiting bakau.

Tabel 3. Kandungan protein dan lemak tubuh serta efisiensi pakan (FE) benih kepiting bakau, $S$. paramamosain yang diberi pakan percobaan ${ }^{1}$

Table 3. Whole body protein, lipid content and feed efficiency (FE) of mud crab juvenile fed with experimental diets

\begin{tabular}{cccc}
\hline $\begin{array}{c}\text { Pakan percobaan } \\
\text { Experimental diet }\end{array}$ & $\begin{array}{c}\text { Protein } \\
\text { Protein (\%) }\end{array}$ & $\begin{array}{c}\text { Lemak } \\
\text { Lipid (\%) }\end{array}$ & FE \\
\hline Lp-0 & $35.3 \pm 0.8^{\mathrm{a}}$ & $3.5 \pm 0.3^{\mathrm{a}}$ & $0.27 \pm 0.04^{\mathrm{a}}$ \\
Lp-3 & $35.0 \pm 0.7^{\mathrm{a}}$ & $3.8 \pm 0.2^{\mathrm{a}}$ & $0.56 \pm 0.13^{\mathrm{b}}$ \\
Lp-6 & $35.8 \pm 0.5^{\mathrm{a}}$ & $4.9 \pm 0.3^{\mathrm{b}}$ & $0.74 \pm 0.06^{\mathrm{bc}}$ \\
Lp-9 & $35.2 \pm 0.1^{\mathrm{a}}$ & $5.7 \pm 0.1^{\mathrm{c}}$ & $0.83 \pm 0.12^{\mathrm{c}}$ \\
Lp-12 & $35.5 \pm 0.6^{\mathrm{a}}$ & $5.8 \pm 0.1^{\mathrm{c}}$ & $0.89 \pm 0.15^{\mathrm{c}}$ \\
\hline
\end{tabular}

1 Nilai pada kolom dengan huruf yang sama tidak berbeda nyata $(P>0,05)$ (Values in the column with the same letter are not significantly different $(P>0.05)$ 
Analisis kandungan protein dan lemak tubuh kepiting menunjukkan bahwa kandungan lemak pakan berpengaruh nyata $(P<0,05)$ terhadap kandungan lemak tubuh kepiting bakau, tetapi tidak berpengaruh nyata terhadap kandungan proteinnya (Tabel 3 ). Kandungan lemak tubuh kepiting berkisar antara $3,5 \%--5,8 \%$ dan meningkat dengan meningkatnya kandungan lemak pakan sampai pada level $9 \%$. Data ini menunjukkan lebih banyak lemak terakumulasi dalam tubuh jika kebutuhan minimalnya sebagai sumber energi dan sumber asam lemak esensial telah terpenuhi. Hasil yang sama juga dilaporkan pada udang galah Macrobrachium rosenbergii yang diberi pakan dengan kandungan lemak berbeda $0 \%--12 \%$ (Sheen \& D'Abramo, 1991). Kandungan protein tubuh benih kepiting bakau berkisar antara $35,0 \%--35,8 \%$ untuk semua perlakuan dan tidak berbeda nyata. Pada percobaan pemberian pakan dengan kandungan protein berbeda terhadap benih kepiting bakau, $S$. paramamosain, Giri et al. (2002) melaporkan bahwa kandungan protein tubuh kepiting perkisar $33,3 \%$-$37,2 \%$ dan kandungan lemaknya berkisar 4,8\%--6,8\% serta dipengaruhi oleh kandungan protein pakan. Prasad \& Neelakantan (1988b) melaporkan komposisi biokimia daging kepiting bakau S. serrata bervariasi menurut ukurannya. Kepiting ukuran kecil dengan lebar karapas 51--80 mm mempunyai kandungan protein lebih tinggi dengan kandungan lemak relatif lebih rendah. Pada kepiting dengan ukuran lebih besar dan yang dewasa dengan lebar karapas $81--130 \mathrm{~mm}$ ditemukan kandungan proteinnya tetap konstan, sedangkan kandungan lemak dan glikoginnya mengalami penurunan. Siddiquie et al. (1987) juga melaporkan bahwa dari $85 \%--95 \%$ bahan kering daging kepiting S. serrata, 55\%--65\% adalah protein. Sementara kandungan karbohidrat dan lemaknya adalah rendah. Hasil yang sama juga dilaporkan George \& Gopakumar (1987) di mana daging kepiting, $S$. serrata mengandung cukup tinggi protein, dengan kandungan lemak dan karbohidrat yang rendah.

\section{KESIMPULAN}

1. Peningkatan kandungan lemak pakan meningkatkan pertumbuhan dan kandungan lemak tubuh benih kepiting bakau.

2. Benih kepiting bakau membutuhkan pakan dengan kandungan lemak $9 \%--12 \%$ untuk dapat tumbuh optimal.

\section{DAFTAR PUSTAKA}

Akiyama, D.M., W.G. Dominy, and A.L. Lawrence. 1991. Penaeid shrimp nutrition for the commercial feed industry: Revised. In Akiyama, D.M. and Tan, R.K.H. (Eds.). Proceedings of the Aquaculture Feed Processing and Nutrition Workshop. Singapore. p. 80--98.
Cann, B. and C. Shelley. 1999. Preliminary economic analysis of mud crab (Scylla serrata) aquaculture in the Northern Territory of Australia. In Keenan, C.P. and Blackshaw, A. (Eds.). Mud Crab Aquaculture and Biology. ACIAR Proceeding. Canberra, 78: 76--79.

Castell, J.D. and J.F. Covey. 1976. Dietary lipid requirement of adult lobster, Homarus americanus. J. Nutr. 106: 1159--1165

Chin, H.C., U.P.D. Gunasekera, and H.P. Amandakoon. 1992. Formulation of artificial feed for mud crab culture: A preliminary biochemical, physical and biological evaluation. In Angell, C.A. (ed.). Report of the Seminar on the Mud Crab Culture and Trade. Surat Thani, Thailand. p. 179--184.

Cholik, F. 1999. Review of mud crab culture research in Indonesia. In Keenan, C.P. and A. Blackshaw (Eds.). Mud Crab Aquaculture and Biology. ACIAR Proceeding. Canberra. 78: 14--20.

Cuzon, G. and J. Guillaume. 1997. Energy and protein: energy ratio. In D'Abramo, L.R., D.E. Conklin, and D.M. Akiyama (Eds.). Crustacean Nutrition. Advances in World Aquaculture, 6: 51--70.

Dat, H.D. 1999. Description of mud crab (Scylla spp.) culture methods in Vietnam. In Keenan, C.P. and A. Blackshaw (Eds.). Mud Crab Aquaculture and Biology. ACIAR Proceeding. Canberra, 78: 67--71.

Davis, D.A. and E.H. Robinson. 1986. Estimation of dietary lipid requirement level of the white crayfish Procambarus acutus. J. World Aquacult. Soc. 17: $37-$ -43 .

Direktorat Jenderal Perikanan. 1999. Statistik Perikanan Indonesia. Departemen Pertanian, Jakarta. 61 pp.

Fortes, R.D. 1999. Preliminary results of the rearing of mud crab, Scylla olivacea in brackishwater earthen ponds. In Keenan, C.P. and A. Blackshaw (Eds.). Mud Crab Aquaculture and Biology. ACIAR Proceeding. Canberra, 78: 72--75.

George, C. and K. Gopakumar. 1987. Biochemical studies on crab Scylla serrata. Fish. Technol. Soc. 24: 57-61 .

Giri, N.A., Yunus, K. Suwirya, dan M. Marzuqi. 2002. Kebutuhan protein untuk pertumbuhan juvenil kepiting bakau, Scylla paramamosain. J. Pen. Per. Indonesia. 8(5): 31--36.

Keenan, C.P. 1997. The fourth species of Scylla. In Keenan, C.P. and A. Blackshaw (Eds.). Mud Crab Aquaculture and Biology. ACIAR Proceeding. Canberra, 78: 48--58

Marasigan, E.T. 1999. Development of practical diet for grow-out of mud crab species Scylla serrata and Scylla tranquebarica. In Keenan, C.P. and A. Blackshaw (Eds.). Mud Crab Aquaculture and Biology. ACIAR Proceeding. Canberra. 78: 187--195.

Millamena, O.M. and E.T. Quinitio. 1999. Reproductive performance of pond-sourced Scylla serrata fed various broodstock diets. In Keenan, C.P. and A. Blackshaw (Eds.). Mud Crab Aquaculture and Biology. ACIAR Proceeding. Canberra. 78: 114--117.

Prasad, P.N. and B. Neelakantan. 1988a. Food and feeding of mud crab Scylla serrata (Decapoda: 
Portunidae) from Karwar waters. Indian J. Fish. 35: $164--170$

Prasad, P.N. and B. Neelakantan. 1988b. Chemical composition of the edible crab, Scylla serrata. Beverage Food World. 15: 37--38.

Sheen, S.S. and L.R. D'Abramo. 1991. Response of juvenile freshwater prawn, Macrobrachium rosenbergii, to different levels of a cod liver/corn oil mixture in a semi-purified diet. Aquaculture. 93: 121$-134$
Siddiquie, P.J.A., Z. Akbar and R. Qasim. 1987. Biochemical composition and calorific values of the three edible species of portunid crabs from Karachi. Journal Science Indonesian Research, 30: 119--121.

Sulaeman dan A. Hanafi. 1992. Pengaruh pemotongan tangkai mata terhadap kematangan gonad dan pertumbuhan kepiting bakau (Scylla serrata). J. Pen. Budidaya Pantai. 8: 55--62.

Steel, R.G.B. and J.H. Torrie. 1960. Principles and Procedures of Statistics. McGraw-Hill, New York. 481 pp. 